\title{
Investigating Difficulties of Self-Study in Reading Skills of English Language Students of the High-Quality Training Program at Can Tho University
}

Ngoc Bao Nguyen, Huan Buu Nguyen, Xuan Hong Thi Pham, Ngoc Nhu Nguyen, Ngoc Yen Nhi Truong

\author{
School of Foreign Languages, \\ Can Tho University, \\ Vietnam
}

\begin{abstract}
Research has indicated that self-study is a constructivist learning approach that promotes student engagement within tertiary education. However, teaching at higher education institutions is largely based on traditional lecture mode and thus, students are likely become passive in their learning process. Moreover, little research has been conducted to look into this constructivist approach perceived by students in English as a foreign language (EFL) classes. These paper therefore examines the difficulties of self-study in reading comprehension classes in high quality program at a university in the Mekong Delta, Vietnam. Data collected in this study included questionnaire and interview. The participants in this study were 75 juniors in English languages and culture studies. The findings from this study indicate that student-related factors such as time, learning environment, and subject-specific vocabulary could hinder them from reading learning. Pedagogical implications and recommendations for students and teachers are provided.
\end{abstract}

Keywords: Difficulties, self-study, reading, high-quality program

\section{Introduction}

Self-study is widely held as a constructivist learning approach which shifts from the traditional lecture mode in which students are not provided an opportunity to determine their own learning process to obtain knowledge of a particular field of study (Jones, 1995; Nguyen and Nguyen, 2020; Tidwell et al., 2011). In recent times, English as a global language (Crystal,2003), has witnessed its role in allowing students to communicate ideas to the intended audiences or other peers while interacting in order to reach academic goals and learning outcomes. There is no exception in Vietnamese education system. In other words, through reading, students can build up their English language proficiency and have good command of its use to respond to the emerging needs to keep up with personal, professional, and future contexts in the global integration (Pham\& Nguyen, 2017).However, students were likely to be passive, inattentive and uncomfortable while learning reading classes. Another difficulty that students encountered during reading is that they failed to figure out the word meanings in a written text; thus, they could not achieve good test scores or end-of-course grades in reading course. Furthermore, Fang (2012) indicates that reading texts challenges student learning with subject-specific text passages and particular field of study such as science, mathematics, and technology, to name a few. Little is known about how students perceived such difficulty while seeking their own way to learn reading may help them to promote their learning within the context of learning English as a foreign language in Vietnamese contexts. This study reported in this paper therefore fills the gap. The research question that guided the study was, "What are the difficulties of self-study encountered by students while learning reading comprehension?" 
DOI: $\underline{10.51386 / 25815946 / \mathrm{ijsms}-\mathrm{v} 4 \mathrm{i} 5 \mathrm{p} 107}$

\section{Literature Review}

This section first presents the definitions of key terms: self-study,reading skills and difficulties in reading. It then reviews related studies relevant to the current study.

\subsection{Self-study}

Self-study plays an important role in how students take responsibility for their ownwith particular regard to learning English as a foreign language (Benson, 2001; Hyland, 2004). There are several definitions of this term in the literature. Brookfield (2009) defines self-study as a process where individual students form the concept, design a study plan, perform and evaluate learning outcomes on their own, and by doing so, this learning approach serves as a tool to supplement and reinforce knowledge learned in class-like a new skill. Others view self-study as a learning method where students direct their own study outside the classroom without direct guidance, supervision or instruction(Bonilla et al., 2021; Grade Power Learning, 2018). Taken these perspectives together, this suggests the idea that self-study is related to a process of learning in which students obtain knowledge of a given field of study by their own endeavors and energy and as a result, develop their ways to achieve their personal or professional learning goals.

\subsection{Reading skills}

Reading skills are considered as one of the most important skills in the field of teaching and learning foreign languages (Tran \& Nguyen, 2017). Reading skills are keys to learning purposes for students who are majoring in English language (Fisher, 1981; Harmer, 2007).Nuttall (2005) asserts that reading skills allow students to interact with written context or course content. It is interesting to note that Smith (2012) argues that reading is not a linear process; rather, it is interactive because students as readers hypothesize, predict, and utilize their prior knowledge to construct new knowledge or make sense of meanings embedded in the text. Likewise, other researchers have advocated that reading is an interactive process in which readers interact with the text using their prior knowledge (Carrell and Grabe, 2013; Grabe, 2009).Drawing on the above conceptualizations, it is likely that reading provides students with an opportunity to better their learningin English while processing information or making sense of particular reading text passages (Hong and Nguyen, 2019).

\subsection{Difficulties in reading skills}

A reading skill is a sophisticated activity that enables learners to decode the meanings from the messages from a particular text; therefore, if learners cannot put words and sentences together for the meaning, then they fail to read or succeed in academic life(Fisher, 1981; Nuttall, 2005). Several studies have addressed that students may find reading difficult for several factors, namely lack of vocabulary, insufficient background knowledge, limited English language proficiency, to name a few.

Yaseen (2013) examined the difficulties in reading skills of English learners and identified ways to overcome the difficulties. These difficulties are related to their learning behavior, book content, method of teaching and teacher's support. 490 EFL students and 94 teachers in Nablus District took part in this study. Questionnaires and interviews were the data gathering tools in this study. The result shows that students identified reading attitudes, book content, teacher's methods, and support as problems while learning reading. Some suggestions to help student with reading difficulties are provided.

Knowing that reading is quite a difficult skill because most English Foreign Language(EFL) learners have many reading problems, Sultana (2016) conducted research on different reading difficulties that university students in Bangladesh have to deal with. These are the lack of vocabulary, the understanding in reading, the obstacles of various topics, and the lack of motivation and encouragement. Data collected in this study include questionnaire and interview. 60 English major students from various universities took part in this study. The findings from this study indicate that students actually meet different reading problems and then give many strategies that help them to solve these difficulties. 
DOI: $\underline{10.51386 / 25815946 / \mathrm{ijsms}-\mathrm{v} 4 \mathrm{i} 5 \mathrm{p} 107}$

Volume: 4 Issue: 5

September to October 2021

https://www.ijssmsjournal.org

A study conducted by Tran and Duong (2018) indicated the difficulties students encountered in English for Specific Purpose (ESP) reading classes. This study was undertaken at a university in Vietnam. Participants were eighty English- majored students who were asked to complete a questionnaire and attend the interviews. The results of this study revealed that students did not have much struggle with reading ESP texts. However, they found it difficult to read the text with specialized knowledge because they lacked vocabulary and knowledge about such subject-specific areas of study. The material type and time pressure also affected their reading comprehension of a particular text. The authors also pointed out that students should learn new vocabulary and technical terms in specialized knowledge to understand the course content and improve their reading performance.

The studies mentioned in the literature above have provided an overview of difficulties encountered by students in reading comprehension in EFL contexts. In particular, the difficulties were identified as lack of vocabulary, poor reading comprehension, a variety of topics, lack of motivation and encouragement, specialized knowledge, time pressure, attitudes, lesson content, and teacher-related factors.

To further understand the difficulties in self-study in reading English language learning and their learning achievements, this study reported in this paper therefore provides insights into the difficulties encountered by English-majored students in high quality program of English studies at a university at the Mekong Delta, Vietnam.

\section{Methodology}

The study was carried out at a university in the Mekong Delta, Vietnam. Participants were 75 third-year students in the high-quality program of English majors. These students already completed all reading courses, so they were assumed to become aware of the difficulties in learning reading compared to the first-year or second-year students of the program. The purpose of this study was to examine students' perceptions of the difficulties in self-study in reading classes through questionnaire and interviews. Seven students were randomly selected for semi-structured interviews in order to deepen understanding of their views of self- study in reading.

A 22-item questionnaire consisting of two parts was distributed to students. The first part of the questionnaire (items 1-6) is related to the background information of the participants (name, gender, major, student's code, email, phone number). The second part (items 7-22) focuses students' perceptions of the reading aspects hindering them from self-study while reading texts. One part of the questionnaire was adopted from the framework of a study by Chau (2009) regarding difficulties in reading comprehension.

Semi-structured interviews were used in this study to explore students' views of self-study and difficulties in learning reading. Interviews were deemed appropriate since it served as a great way to supplement the data obtained from the questionnaires (Fraenkel, Wallen, \&Huyn, 2009). In addition, this type of interview was seen crucial to explore the topic of interest or under investigation which was not directly observed (Mackey \&Gass, 2005). Each interview took approximately 15 minutes. The interview questions were all written in English and then translated into Vietnamese. It was conducted in Vietnamese so that the participants could express their ideas in a clear and natural way. The interview data were recorded, transcribed, and organized using thematic analysis (Boyatzis, 1998).

\section{Findings}

\subsection{Insights into students' perceived difficulties in self-study in reading}

The Descriptive Statistics was run to check the mean score of student's difficulties in self-study in reading, as shown in Table 4.1.

Table 4.1 Overall score of perceived difficulty in self-study

\begin{tabular}{|l|l|l|l|l|l|}
\hline & N & Min & Max & M & SD \\
\hline Total mean & 75 & 3.12 & 4.39 & 3.85 & .45 \\
\hline Valid N (listwise) & 75 & & & & \\
\hline
\end{tabular}


DOI: $\underline{10.51386 / 25815946 / \mathrm{ijsms}-\mathrm{v} 4 \mathrm{i} 5 \mathrm{p} 107}$

Volume: 4 Issue: 5

September to October 2021

https://www.ijsmsjournal.org

Table 4.1 shows that the total mean score of students' perceived difficulties in self-study in reading classes was at a high level $(M=3.85, S D=.45)$. This result indicates that the participating students found self-study in reading difficult. A One-Sample t-Test was administered to evaluate whether there was a significant difference in the mean score of students' difficulties in self-study in reading, from the test value 3.0, the accepted mean for the average level. The result of the One-Sample $t$-Test indicates that there was a significant difference $(t=7.55 ; d f=74 ; p=.00)$. Therefore, it can be concluded that students believed they encountered difficulties of self-study in reading.

\section{Students' perceptions of reading}

\section{Table 4.2 Students' perceptions of reading}

\begin{tabular}{cccccc}
\hline Items & $\mathrm{N}$ & Min & Max & M & SD \\
\hline 1 & 75 & 2 & 5 & 3,56 &, 827 \\
\hline 2 & 75 & 1 & 5 & 3,51 &, 844 \\
\hline 3 & 75 & 1 & 5 & 3,87 & 1,095 \\
\hline 4 & 75 & 1 & 5 & 2,27 &, 981 \\
\hline 6 & 75 & 1 & 5 & 3,58 &, 986 \\
\hline
\end{tabular}

The overall average scores in Table 4.2 indicate that the participating students perceived the importance of reading in relation to self-study during reading lessons. In particular, with regard to item 1, they agreed that reading is an interactive process between the learner, context and the author $(M=3.56 ; S D=.826)$. When asked if students were able to apply what they self-studied in reading (item 3), students indicated that the skills learned in reading class allowed them to better reading performance $(M=3.87 ; S D=0.844)$, and this was recorded the highest level. Students considered that they found it difficult to self-study in reading (item 6) $(M=3.75 ; S D=.986)$ because they were not able to self-study in reading (item 2) $(M=3.51 ; S D=.827)$. Regarding time spent reading on their own, students reported the need for spending more time reading $(M=3.58 ; S D=.981)$. However, students thought that learning in class was enough, and that they did not need to practice more (item 4) $(M=2.27, S D=1.095)$. In general, students' perceptions of self-study in reading were positive.

\subsection{Statistical analysis of barriers to self-study in reading}

Table 4.3 Overall mean score of student's barriers on self-study in reading

\begin{tabular}{cccccc}
\hline & $\mathrm{N}$ & Min & Max & M & SD \\
\hline Total Mean & 16 & 1 & 5 & 3.22 & 1.02 \\
\hline
\end{tabular}

As shown in Table 4.3, the total mean score of the students' barriers on self-study in reading $(M=3.22)$ was above average on a scale. Analysis of the questionnaire data reveals that the participants had difficulty in learning reading. 
DOI: $\underline{10.51386 / 25815946 / \text { ijsms-v4i5p107 }}$

Volume: 4 Issue: 5

September to October 2021

https://www.ijsmsjournal.org

To determine the types of difficulties of self-study in reading, a Descriptive Statisticswas run to check the mean scores of the dimensions of students' barriers on self-study while reading (16 items). The results are illustrated in Table 4.4.

\begin{tabular}{|c|c|c|c|c|c|}
\hline & $\mathbf{N}$ & Min & Max & $\mathbf{M}$ & SD \\
\hline limited vocabulary & 75 & 1 & 5 & 3.92 & .997 \\
\hline inability to guess words in context & 75 & 1 & 5 & 3.28 & 1.097 \\
\hline specialized vocabulary & 75 & 1 & 5 & 3.76 & .819 \\
\hline $\begin{array}{l}\text { Insufficient in using existing knowledge to analyzing } \\
\text { a reading passage }\end{array}$ & 75 & 1 & 5 & 3.00 & .944 \\
\hline strange topic & 75 & 1 & 5 & 3.52 & 1.044 \\
\hline Unable to do when reading & 75 & 1 & 5 & 2.67 & 1.107 \\
\hline Unable to identify the gist & 75 & 1 & 5 & 2.93 & 1.095 \\
\hline time-consuming to translate into Vietnamese & 75 & 1 & 5 & 3.13 & 1.095 \\
\hline time-consuming to read passage many times & 75 & 2 & 5 & 3.64 & .799 \\
\hline no motivation & 75 & 1 & 5 & 3.17 & 1.107 \\
\hline unable to make inferences & 75 & 1 & 5 & 3.11 & .953 \\
\hline unable to analyze a reading & 75 & 1 & 5 & 3.07 & 1.018 \\
\hline no reading skills (skimming, scanning) & 75 & 1 & 5 & 2.72 & 1.047 \\
\hline no habit of practicing reading skills & 75 & 1 & 5 & 3.31 & 1.090 \\
\hline no passion or motivation to read & 75 & 1 & 5 & 2.96 & 1.132 \\
\hline no particular strategy in reading & 75 & 1 & 5 & 3.39 & 1.038 \\
\hline
\end{tabular}

As shown in Table 4.4, students reported that their ability to guess words based on their context was just abovethe average level $(M=3.28 ; S D=1.097)$ and they found it difficult to apply what they knew to the task to analyze a new reading passage $(M=3.00 ; S D=0.944)$. Moreover, they said they could not grasp the main idea of the text and did not enjoy reading, as well as become indulged in self-study in reading skills. The mean scores for these two items are not at a high level $(M=2.93 ; S D=1.095 ; M=2.96 ; S D=1.132$, respectively).

Regarding time-consuming issue, most of the students agreed that it took time to read the passage many times $(M=3.64 ; S D=.799)$, as well as to translate the text into Vietnamese $(M=3.13 ; S D=1.095)$. In addition, students found unfamiliar topics $(M=3.52 ; S D=1.004)$, lack of motivation and self-discipline in self-study in reading to be the barriers $(M=3.17 ; S D=1.107, M=3.31 ; S D=1,090$, respectively). Moreover, students thought that limited vocabulary $(M=3.92 ; S D=.997)$, and specialized vocabulary $(M=3.76 ; S D=.819)$ were the difficulties for them while self-studying reading. In terms of the essential skills when learning reading, students were unable to reason while reading the passage $(M=3.11 ; S D=.953)$; they had difficulty in analyzing the text and did not possess the skills to work with reading strategies such as skimming and scanning $(M=3.07, S D=1.018 ; M=2.72, S D=1.047$, respectively).Students mentioned that they did not have any reading strategy for practicing self-study $(M=2.67, S D=$ $1.107)$ and they did not know what to do before reading $(M=3.39 ; S D=1.038)$.

\subsection{Findings from the interview}

This section focuses on students' perceptions of self-study in reading skills in relation to difficulties that they encountered while learning to read. The seven interviewed students acknowledged the value of reading comprehension. Five students believed that self-study in reading aids in the speeding up of learning and the acquisition of new knowledge. The following extracts illustrate their views. The following extracts illustrate their views: 
DOI: $\underline{10.51386 / 25815946 / \text { ijsms-v4i5p107 }}$

Volume: 4 Issue: 5

September to October 2021

https://www.ijssmsjournal.org

"Self-study in reading is really necessary because the time spent in class is very little, the curriculum is a lot, the teacher can only answer a part of the question, but not teach me all in the textbook. Self-study in reading also helps to find a suitable new learning method and helps speed up the learning process. In addition, when self-study in reading, I will be an active person to explore and absorb knowledge, so it is easier to remember knowledge."

(Student 1, interview extract)

"Because class time is limited, I am unable to clearly understand the questions even after studying. So I always taught myself to read at home. When I investigate a topic on my own, it motivates me to actively seek information. From there, I can think about topics in greater depth and make connections between what I'm learning. This allows me to absorb new information and remember it more easily."

(Student 2, interview extract)

The learning environment was recorded to impact on students' self-study in reading. Noise was reported as the first influencing factor. The following examples reveal students' views.

"The environment around the residence affects one's self-study in reading. The reason is because reading requires a lot of concentration, if the surrounding environment is too noisy, it will be difficult to concentrate. As a result, this noisy atmosphere interferes with our concentration and understanding of the reading content. In fact, I cannot complete the task assigned by the teacher."

(Student 2, interview extract)

"I prefer to study in a peaceful atmosphere, where I am less distracted by noise and other people. I generally study alone so that I am not distracted and can concentrate the best."

(Student 5, interview extract)

"I prefer to study in a peaceful atmosphere, where I am less distracted by noise and other people. I generally study alone so that I am not distracted and can concentrate the best."

(Student 7, interview extract)

While writing a summary for a reading passage, all of eight students indicated that they lacked vocabulary and grammatical structures. The following two examples illustrate their views.

"Regarding the difficulty in self-study in reading, firstly, because there are many new words, I will encounter the problem of both doing the test and looking up the dictionary, which will make me lose interest in working. Secondly, because there are many structures when translating into my native language, I do not understand well and do not translate the author's intentions correctly. Thirdly, a word can have many meanings, in this context have different meanings, so it will take me a lot of time and even literary measures that make it difficult for me to understand in this reading."

(Student 6, interview extract)

"I also struggle with sefl-study and reading. The first consideration is specialized vocabulary. It's perplexing because the specialized meaning is frequently very different from common sense. The second issue is with grammar; sometimes with complicated structures, I'm not sure if I'm correctly understanding and translating the author's ideas."

(Student 7, interview extract) 
DOI: $\underline{10.51386 / 25815946 / \mathrm{ijsms}-\mathrm{v} 4 \mathrm{i} 5 \mathrm{p} 107}$

\section{Discussion, implications and recommendations 5.1. Discussion}

The findings from the study indicate that participating students reported the difficulties of self-study in English reading comprehension skills. This isin line with those of studies by Connolly and Dockrell (2009), Fang (2012), and Oakhill and colleagues (2019). These authors indicate that challenges come mainly from lack of knowledge about many fields, lack of vocabulary in specific-subjects or technical terms; inattentiveness and noise.

The findings from the study illustrate that participating students recognized the significance of self-study while learning reading despite perceived difficulties. The challenges were found as vocabulary, unfamiliar topics, and reading time. Particularly, most students considered a lack of vocabulary as the most hindering factor influencing students' self-study in reading. This finding is in line with those from other studies which addressed the importance of vocabulary in self-study in reading skills (Adam, 1982; Zhang,2010).

The interview data are aligned with the quantitative survey in ways that participating students said selfstudy was useful as it could assist them in improving knowledge in many sub skills in reading. These include thinking skills and soft-skills. However, these interviewees revealed some difficulties while studying reading. These difficulties that hindered students from self-study in reading were identified as lack of vocabulary, namely technical terms or subject-specific ones and noise.

\subsection{Implications and Recommendations}

There are some pedagogical implications and recommendations for school administrators, teachers and students.

The findings from the current study give rise to the importance of self-study literature with regard to teaching and learning reading of English as a foreign language at tertiary educational contexts, particularly in the Mekong Delta, Vietnam. It is recommended that school administrators of Foreign Languages should organize seminars on self-study skills for first-year students, especially reading skills. Additionally, it is preferable to design a learning space or reading zone at the Department of English, such as an English-speaking coffee shop or a reading research-oriented corner, where students can create their own learning environment beyond the walls of classroom in order to share ideas, discuss with other peers about choosing the appropriate articles or books to read for their own, thereby enhancing other sub skills like critical thinking and problem-solving skills. It is the English club as a self-study corner that functions as a platform or forum where students can study in pairs or in groups to use English in an informal and natural setting. If this can be done, students' sharing of personal self-study experiences in English skills can inspire other peers to raise awareness of the true meaning of self-study in reading English.

It is important for teachers to consider ways to provide learning opportunities for students in reading classes so that students will take greater responsibility for their self-study, heighten their interest and participate actively in experiencing a wide range of reading resources. More importantly, teachers need to direct students' weekly study plans to ensure students' self-study activities can be obtained.

The value of self-study in reading classes was perceived by participating students; therefore, this allows them to retrospect their reading practices, cultivate the reading habits, and develop their own ways to obtain and digest new knowledge from what they have learned or experienced in their learning process. Or in other words, for all challenges students encountered in comprehending a reading text, students need to explore the strategies and skills that they could use to enhance their reading ability. In particular, to deal with the lack of vocabulary, students should learn how to guess new words in context instead of looking up every new word right away in the dictionary whenever they read.

\section{Conclusions}

The study aims to explore the difficulties of self-study reported by students while learning English reading skills. Self-study has its value and this learning approach with students' reading ability and sub-skills. The findings of this 
DOI: $10.51386 / 25815946 /$ ijsms-v4i5p107

study provide teachers and students with insightful views on how self-study influences student learning to read better. As such, teachers and students need to shift their roles to facilitate their instructional approaches and learning styles respectively, thereby improving the quality of teaching and learning in reading comprehension in the long run.

\section{About the Authors:}

Ngoc Bao Nguyen is an English-majored junior of School of Foreign Languages, Can Tho University. She is interested in English studies and self-study in learning reading skills.

HuanBuu Nguyen is Associate Professor, School of Foreign Languages, Can Theo University. His research interests include action research, teacher change, beliefs and active learning.

Hong Thi Xuan Pham is a third-year student of School of Foreign Languages, Can Tho University. Her research interests include effective learning strategies.

Ngoc Nhu Nguyen is an English-majored junior of School of Foreign Languages, Can Tho University. She has passion for learning new ways to help other learners identify challenges and solve problems.

Nhi Ngoc Yen Truong is anEnglish-majored junior of School of Foreign Languages, Can Tho University. She is passionate about reading and writing skills and expects to raise other learners' awareness of the difficulties of selfstudy.

\section{References}

[1] Adams, S. (1982). Scripts and the recognition of unfamiliar vocabulary: Enhancing second language reading skills. The Modern Language Journal, 66 (2), 155-159.

[2] Anderson, N.J. (2003). Reading. In D. Nunan(Ed.). Practical English language teaching (pp.67-86). McGraw-Hill.

[3] Andrianova, N. S., Nizamieva, L. R., Nazarova, G. I., Ostroumova, O. F., \& Leblanc, C. (2017). The development of students' cognitive self-study while teaching reading in FL training.Journal of History Culture and Art Research,6(5),321-326. https://dx.doi.org/10.7596/taksad.v6i5.1258

[4] Benson, P. (2001). Teaching and researching autonomy in language learning. London: Longman.

[5] Bonilla, C., Hughes, M.M., Tare, M., \&Vatz, K. (2021). Self-study in language learning: Relationships among time, activities, and learning outcomes. Foreign Language Annals 54(2),452-475 https://dx.doi.org/10.1111/flan.12520

[6] Connolly, D., \& Dockrell, J. (2019). The effects of classroom noise on the reading comprehension of adolescent. The Journal of the Acoustical Society of America, 145(1), 372-381.

[7] Crystal, D. (2003). English as a global language ( $2^{\text {nd }}$ Ed.) America: Cambridge University Press.

[8] Chau, H. T. (2009). Difficulties in reading comprehension: A case study of the first-year English-major students at Tay Do university, Master thesis in Education, Can Tho.

[9] Fang, Z. (2012). The challenges of reading disciplinary texts. In T. L. Jetton \& C. Shanahan (Eds.), Adolescent literacy in the academic disciplines: General principles and practical strategies (pp. 34-68). Guilford Press.

[10] Grabe, W. (2009). Reading in a second language: Moving from theory to practice. Cambridge: Cambridge University Press.

[11] Grade Power Learning (2018). Retrieved on 10 June 2021 from https://gradepowerlearning.com/what-is-self-study

[12] Hong, T.D., \& Nguyen, H.B. (2019). Teacher beliefs and practices of scaffolding students' reading comprehension through questioning at pre-reading stage. European Journal of Foreign Language Teaching 4(2), 72-92.https://dx.doi.org/10.5281/zenodo.3270743

[13] Hyland, F. (2004). Learning autonomously: Contextualizing out-of-class English language learning. Language Awareness 13(3), 180-202 https://dx.doi.org/10.1080/09658410408667094 
DOI: $\underline{10.51386 / 25815946 / \text { ijsms-v4i5p107 }}$

Volume: 4 Issue: 5

September to October 2021

https://www.ijsmsjournal.org

[14] Jones, J.F. (1995). Self-access and culture: Retreating from autonomy ELT Journal 49(3), 228-234 https://dx.doi.org/10.1093/elt/49.3.228

[15] Kadir, N. A., Subki, R. N., Jamal, F., Ismail, J. (2014). The importance of teaching critical reading skills in Malaysian reading classroom. Paper presented at the 2014 WEI International Academic Conference Proceedings, Bali, Indonesia.

[16] Lefevre, C. A. (1964). Linguistics and the teaching of reading: Curriculum and methods in education. McGraw-Hill Companies.

[17] Nguyen, H.B., \& Nguyen, T.A. (2017). English for Specific Purposes (ESP): Perceptions of students and teachers of learning needs at a Vietnamese school. International Journal of Advanced Research, 5(4), 793-803. https://dx.doi.org/10.1474/IJAR01/3877

[18] Nguyen, P.N., \& Nguyen, T.Q. (2020). $9^{\text {th }}$-grade students' competence of out-of-class self-regulated learning: A case study at Nghia Tan secondary school located in Hanoi, Vietnam Vietnam Journal of Education Sciences, 16(2), 103-110.

[19] Nuttall, C. (2005). Teaching reading skills in a foreign language. Oxford, UK: Macmillan Education.

[20] Oakhill, J. V., Cain, K., \&Elbro, C. (2019). Reading comprehension and reading comprehension difficulties. In D. A. Kilpatrick, R. M. Joshi, \& R. K. Wagner (Eds.), Reading development and difficulties: Bridging the gap between research and practice (pp. 83-115). Springer. https://doi.org/10.1007/978-3-030-26550-2_5

[21] Sultana, N. (2016). Assessing reading difficulties and reading strategies in the context of Bangladesh: Tertiary level, Master thesis in English, BRAC University.

[22] Tidwell, D., Wymore, L., Garza, A, Estrada, M., \& Smith, H. (2011). Creating a professional learning community through self-study. Studying Teacher Education: A Journal of Self-Study of Teacher Education Practices, $7(3), \quad 315-330$ https://dx.doi.org/10.1080/17425964.2011.617152

[23] Tran, T.Q., \& Duong, T.M. (2018). The difficulties in ESP reading comprehension encountered by English-majored students. VNUJournal of Foreign Studies, 34(2),151-161.

[24] Yaseen, A. (2013). The reading difficulties in English and how to deal with them as perceived by teachers and students in Nablus district,Master thesis, an-Najah National University.

[25] Zhang, L., \&Anual, S. (2008). The role of vocabulary in reading comprehension. Regional Language Centre Journal, 39 (1), 51-76.

[26] Zhang, C. (2010). The teaching of reading comprehension under the psychology schemata theory. Journal of Language Teaching and Research. 1(4), 457-459. 